\title{
MANAGEMENT OF COFFEE LEAF MINER: SPRAY VOLUME, EFFICACY OF CARTAP HYDROCHLORIDE AND IMPACT ON PARASITISM
}

\author{
Thiago Lima Melo르, Carlos Gilberto Raetano², Moizés Silva Nery³, Adriana Dias Cardoso ${ }^{4}$, \\ Aldenise Alves Moreira ${ }^{5}$, Suzany Aguiar Leite ${ }^{6}$, Thamires Francisca de Jesus ${ }^{7}$, \\ Wesley Gil Oliveira Silva ${ }^{8}$, Maria Aparecida Castellani ${ }^{9}$
}

(Received: April 16, 2019; accepted: June 03, 2019)

\begin{abstract}
The leaf miner is a key pest of coffee and the use of insecticides for its control results in high water consumption. The objective in this study was to evaluate the quali-quantitative aspects of reduced spray volumes with and without the addition of adjuvant, the efficacy of the insecticide cartap hydrochloride in the control of the pest and its effects on the parasitism. Two experiments were carried out in coffee plantations in São Desiderio, BA. Initially, solution of Brilliant Blue tracer $\left(0.15 \% \mathrm{p} \mathrm{v}^{-1}\right)$ of the 43, 112, 146 and $309 \mathrm{~L} \mathrm{ha}^{-1}$ volumes was sprayed with and without the soybean oil methyl ester adjuvant $\left(0.25 \% \mathrm{v} \mathrm{V}^{-1}\right)$. Before spraying, water-sensitive cards were fixed to the plants and subsequently used for analyze the droplet spectrum in Gotas 1.0 software. The tracer deposit was determined by spectrophotometry. Posteriorly, the insecticide cartap hydrochloride $(0.5$ $\mathrm{kg}$ a.i. $\mathrm{ha}^{-1}$ ) was applied in the same volumes and types of spray used in the first test. Infestation rates of pest and parasitism were evaluated before and after application of the insecticide. The quali-quantitative aspects of the sprays were affected by the volume of spray applied, by the adjuvant and by the interaction of the factors. The intermediate volumes yielded better spraying quality without the presence of the adjuvante, with higher number and desity of drops. The spraying volume affected the depoisto the Brilliant Blue tracer in a linear and positive form. The efficacy of the insecticide was prolonged with the lowest volume spray and with adjuvant and its impact on parasitism varied with the volume applied and time after application.
\end{abstract}

Index terms: Adjuvant, application technology, Coffea arabica, Leucoptera coffeella, spraying tracer.

\section{MANEJO DO BICHO-MINEIRO: VOLUME DE PULVERIZAÇÃO, EFICÁCIA DO CLORIDRATO DE CARTAPE E IMPACTO NO PARASITISMO}

\begin{abstract}
RESUMO: O bicho-mineiro é praga-chave do cafeeiro e o uso de inseticidas para seu controle resulta em consumo elevado de água. Objetivou-se avaliar aspectos quali-quantitativos das pulverizações com volumes reduzidos de calda, com e sem adição de adjuvante, a eficácia do inseticida cloridrato de cartape no controle da praga e efeitos no parasitismo. Dois experimentos foram conduzidos em cafezal em São Desidério, BA. Inicialmente, pulverizou-se solução do marcador Azul Brilhante $(0,15 \% \mathrm{p}$ $\left.\mathrm{v}^{-1}\right)$ nos volumes de 43,112, 146 e $309 \mathrm{~L} \mathrm{ha}^{-1}$, com e sem o adjuvante éster metílico de óleo de soja $\left(0,25 \% \mathrm{v} \mathrm{v}^{-1}\right)$. Antes das pulverizações, cartões hidrossensíveis foram fixados nas plantas e, posteriormente, usados para análise do espectro de gotas no software Gotas 1.0. O depósito do marcador foi determinado por espectrofotometria. Posteriormente, foi feita aplicação do inseticida cloridrato de cartape $\left(0,5 \mathrm{~kg}\right.$ de a.i ha $\left.{ }^{-1}\right)$, nos mesmos volumes e tipos de calda utilizados no primeiro ensaio. Os índices de infestação e de parasitismo foram avaliados antes e após a aplicação do inseticida. Os aspectos quali-quantitativos das pulverizações foram afetados pelo volume de calda aplicado, pelo adjuvante e pela interação dos fatores. Os volumes intermediários proporcionaram melhor qualidade das pulverizações sem a presença do adjuvante, com maiores número e densidade de gotas. O volume de pulverização afetou o depósito do marcador Azul Brilhante de forma linear e positiva. A eficácia do inseticida foi prolongada com o menor volume de calda com adjuvante e seu impacto no parasitismo variou com o volume aplicado e tempo após aplicação.
\end{abstract}

Termos para indexação: Adjuvante, tecnologia de aplicação, Coffea arabica, Leucoptera coffeella, traçador de pulverização.

\section{INTRODUCTION}

Bahia is the fourth largest domestic coffee producer, with a yield of 2.1 million processed bags. In 2016, there was a reduction in the harvest of Coffea arabica L. in Bahia, due to the effects of long drought in the main producing regions of the state, high temperatures that affected the flowering and yield of crops in the West of Bahia (CONAB, 2016), besides the and occurrence of high populations of leaf miner, Leucoptera coffeella (Guérin-Mèneville \& Perrottet, 1842) (Lepidoptera: Lyonetiidae). This insect is responsible for indirect damage to the production due to leaf lesions caused by caterpillars, with consequent defoliation, reduction in photosynthesis and coffee longevity (REIS; SOUZA, 2002). In the West of Bahia, the pest has optimal conditions for its development, such as high temperatures and low relative

\footnotetext{
1,4,5,6,7,8,9 Universidade Estadual do Sudoeste da Bahia/UESB - Campus Vitória da Conquista - Cx.P. 95 - 45031-900 - Vitória da Conquista - BA - thiagolimelo@bol.com.br, adriuesb@yahoo.com.br, aldenise.moreira@gmail.com, suzanyleite@yahoo.com.br, thamires19@outlook.com,wesleygiloliveira@yahoo.com, castellani@uesb.edu.br

${ }^{2}$ Universidade Estadual Paulista Júlio de Mesquita Filho/UNESP - Faculdade de Ciências Agronômicas/FCA - Departamento de Proteção Vegetal-18.610-034 - Botucatu - SP- raetano@fca.unesp.br

${ }^{3}$ Universidade Estadual do Sudoeste da Bahia/UESB - Campus Itapetinga - 45.700-000- Itapetinga - BA - mnery@uesb.edu.br
} 
humidity, resulting in a fast cycle, greater number of generations per year and infestations over $20 \%$ of mined leaves throughout the year. Chemical control is practically the only control tactic used, reaching 17 annual applications of insecticides, being two soil applications and 15 sprays (CASTELLANI et al., 2016), frequently without the rotation of active ingredients and without taking into account the principles of integrated pest management and application technology.

The importance of applying phytosanitary products to agricultural crops and the growing concern over safety and environmental responsibility have encouraged the development of new technologies aimed at reducing risks. There is a tendency to reduce the application volume, both to increase the operational capacity of application machines and to reduce water consumption (CHAIM, 2012). Lower application rates may increase product coverage and efficiency, increase the operational capacity of sprayers, and decrease production costs (TAVARES et al., 2017). Application technology is based on the correct application of the active ingredient in the target, in an economical way, affecting the environment as little as possible, in order to maximize efficiency. Studies related to spray equipment associated with spray volumes (MIRANDA et al., 2012), the potential of adjuvants to reduce drift in agricultural spraying (OLIVEIRA etal., 2013) and the reduction in the spray volumes in coffee (SILVA et al., 2014; DECARO JUNIOR et al., 2015, GITIRANA NETO et al., 2016; SOUSA JÚNIOR et al., 2017), have been developed with promising results. The deposition and losses of applied products are influenced by the morphological characteristics of plants and leaves, such as hairiness, cuticular surface, shape and roughness, as well as plant architecture (SANTINATO et al., 2017). The use of adjuvants can reduce the negative influence of the medium, from the preparation of the nozzle to the contact with the target, breaking physical and chemical barriers and facilitating the penetration of the insecticide.

Integrated pest management has one of its basic components in the selectivity of insecticides, allowing the preservation of natural enemies. Studies on the selectivity of phytosanitary products recorded for coffee cultivation have been specifically developed in favor of predators (ROCHA et al., 2010; 2011; VILELA et al., 2010; CASTILHOS et al., 2017), and there is a lack of information about the effects on parasitoids.
In view of the above, the objective of this study was to select a spraying operating system that guarantees efficiency in the control of leaf miner and good quality of the sprays, with a reduction in the application volume and the impact on the natural parasitism of this pest insect.

\section{MATERIAL AND METHODS}

The experiments were carried out from February to May 2016, in a 'Catuaí' coffee

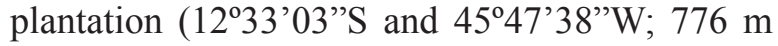
altitude), located in São Desidério, BA. The crop consisted of 12-year-old plants with a height of 2.2 $\mathrm{m}$, with a spacing of $3.2 \times 0.5 \mathrm{~m}$, with central pivot irrigation, comprising an area of $100 \mathrm{ha}$, in which the experimental area (1 ha) was demarcated.

The qualitative-quantitative aspects of spraying were evaluated using a entirely randomized design (due to the high uniformity of the area), in a $4 \times 2$ factorial scheme, with four nozzle volumes $(43 ; 112 ; 146$ and $309 \mathrm{~L}$ $\mathrm{ha}^{-1}$ ) and two types of spray (with and without adjuvant), totaling eight treatments, with three replicates. The plots consisted of three coffee lines with a length of $30 \mathrm{~m}$, and the central line was considered useful for evaluations. The treatments consisted in the spraying of a solution of Brilliant Blue tracer (FD\&C no. 1) at $0.15 \%$ $\left(\mathrm{p}^{-1}\right)$, selected for the studies due to its good stability to sunlight (ALVES et al., 2014), at the four spray volumes, with or without the addition of $0.25 \%\left(\mathrm{v} \mathrm{v}^{-1}\right)$ soybean oil methyl ester (Aureo) based adjuvant. The application was made using a John Deere tractor (5090 E), at a speed of $7.8 \mathrm{~km}$ $\mathrm{h}^{-1}$, with transmission rotation at 540 RPM power take-off and $550 \mathrm{kPa}$ pressure for all treatments. The sprayer used was a Jacto (Arbus 2000), with capacity of 2000 L, 36 nozzles, assisted by air from axial fan with a diameter of $850 \mathrm{~mm}$ and air flow of $19 \mathrm{~m}^{3} \mathrm{~s}^{-1}$. Only the hydraulic system on the left side of the sprayer with 18 tips was used, whose three were of the Magnojet brand, Series X $(0.5 ; 1.0$ and 1.5$)$, empty conical jet with an angle of $85^{\circ}$ at $100 \mathrm{lbf} \mathrm{pol}^{-2}$ and one of the Micron brand, $\mathrm{BH}$ (1.0), also of empty conical jet.

Water-sensitive cards $(76 \times 26 \mathrm{~mm})$ were fixed on the adaxial side of leaves of the upper third (plant height between 141 and $220 \mathrm{~cm}$ ), in two plants per plot, positioned between the 3rd and 5th pair of plagiotropic branches and two sprayed sides of the plants, totaling four per plot. After spraying, the papers were removed and sent to the laboratory for scanning the images 
of the cards in a 600 dpi resolution scanner with subsequent submission to the analysis in the Gotas 1.0 software, obtaining the following variables: number, diameter and density of drops, volumetric mean diameter (VMD), numerical mean diameter (NMD), uniformity coefficient; coverage and recovered spray volume. For quantitative evaluation, a leaf positioned next to each card was collected and packed in a plastic bag and all the leaves collected were sent to the laboratory for washing and recovery of the tracer. The abaxial and adaxial surfaces of the leaves were washed with $20 \mathrm{~mL}$ of distilled water and the resulting solution was subjected to a spectrophotometer to read the absorbance at a wavelength of $630 \mathrm{~nm}$. Leaf area was individually determined with a bench meter. For the calculation of the deposits, the concentrations of Brilliant Blue tracer (ppm) at different dilutions were determined. From these data, the standard curve $(\mathrm{y}=0.0013+1.2812 \mathrm{x}$; $\left.\mathrm{R}^{2}=0.99\right)$ was constructed between absorbance readings and concentrations (ppm). As the spray concentration was the same for all volumes, the amount of tracer was proportional to the spray volume, using the same equation for all treatments. From there, the values of the deposits were calculated as a function of the initial volume and leaf area of each sample.

To determine the efficiency of the insecticide cartap hydrochloride in the control of leaf miner and the impact of the sprays on the natural parasitism of the pest, a second experiment was conducted in the same experimental area used in the previous study. A completely randomized design was used in a $4 \times 2+1$ factorial scheme, with four spray volumes $\left(43 ; 112 ; 146\right.$ and $309 \mathrm{~L}^{-}$ $\left.{ }^{1}\right)$, two types of spray (with and without adjuvant) and one control treatment (without application of insecticide), totaling nine treatments, with three replicates. The plots presented the same constitution described for the previous experiment. The spray was prepared with and without the soybean oil methyl ester (Aureo) based adjuvant. The spray tips used were the same as those mentioned for the first experiment, with correction of the doses in each applied volume. The tractor and sprayer used, as well as the general procedures, were the same as described in the previous experiment.

The infestation and natural parasitism of leaf miner were evaluated through four samplings, one before the application (previous) and 15, 30 and 45 days after application (DAA) of the insecticide. Samples were taken in the upper third of four plants taken at random per plot, and the fourth pair of adult leaves on all four sides of the plant was collected, totaling eight leaves per plant and 32 per plot. A stereoscope was used to count infested leaves (those containing at least one live larvae lesion), and the leaves containing mines with the presence of pupae of parasitoids and/or exit holes of parasitoids, followed by the methodology described by Melo et al. (2007). Infestation rates and natural parasitism were obtained using the formulas: Infestation Index (\%) $=$ (number of leaves with live caterpillars in mines/ total number of leaves) x 100; Parasitism index $(\%)=($ number of parasitized mines/total number of mines) x 100. The formula of Henderson and Tilton (1955) was used to calculate the efficiency of the insecticide and that of Abbott (1925), for parasitism reduction. The toxicity classification of the insecticide was performed according to the scale of the International Organization for Biological and Integrated Control of Noxious Animals and Plants (IOBC) (BOLLER et al., 2005), as a function of the reduction in the parasitoid population: Innocuous or slightly toxic (N): 0 to $50 \%$; Moderately Toxic (M): 51 to $75 \%$; Toxic (T): above $75 \%$.

For all variables, the data were submitted to the Cochran and Bartlett tests to verify homogeneity and of Lilliefors to verify the normality of the variances and when necessary the data were transformed in $\sqrt{ }(x+0.5)$ to meet the assumptions of the analysis of variance. In the quali-quantitative studies, the data for the adjuvant factor were compared by the F test and, for the source of spray volume variation a Regression Analysis was performed at 5\% probability. For the infestation data, the means were compared by the Dunnett test at $5 \%$ probability. All analyses were performed using the SAEG (System for Statistical and Genetic Analysis), version 9.1 (RIBEIRO JÚNIOR, 2001).

\section{RESULTS AND DISCUSSION}

A significant effect $(p<0.05)$ of spray volume was observed for drop number, diameter and density, volumetric mean diameter and uniformity and of adjuvant for drop number, diameter and density, besides uniformity. As for the interaction volume and adjuvant, there was significance for number and density of drops. Quadratic effects of volume for number and density of drops and linear positive for diameter were verified (Figure 1). 

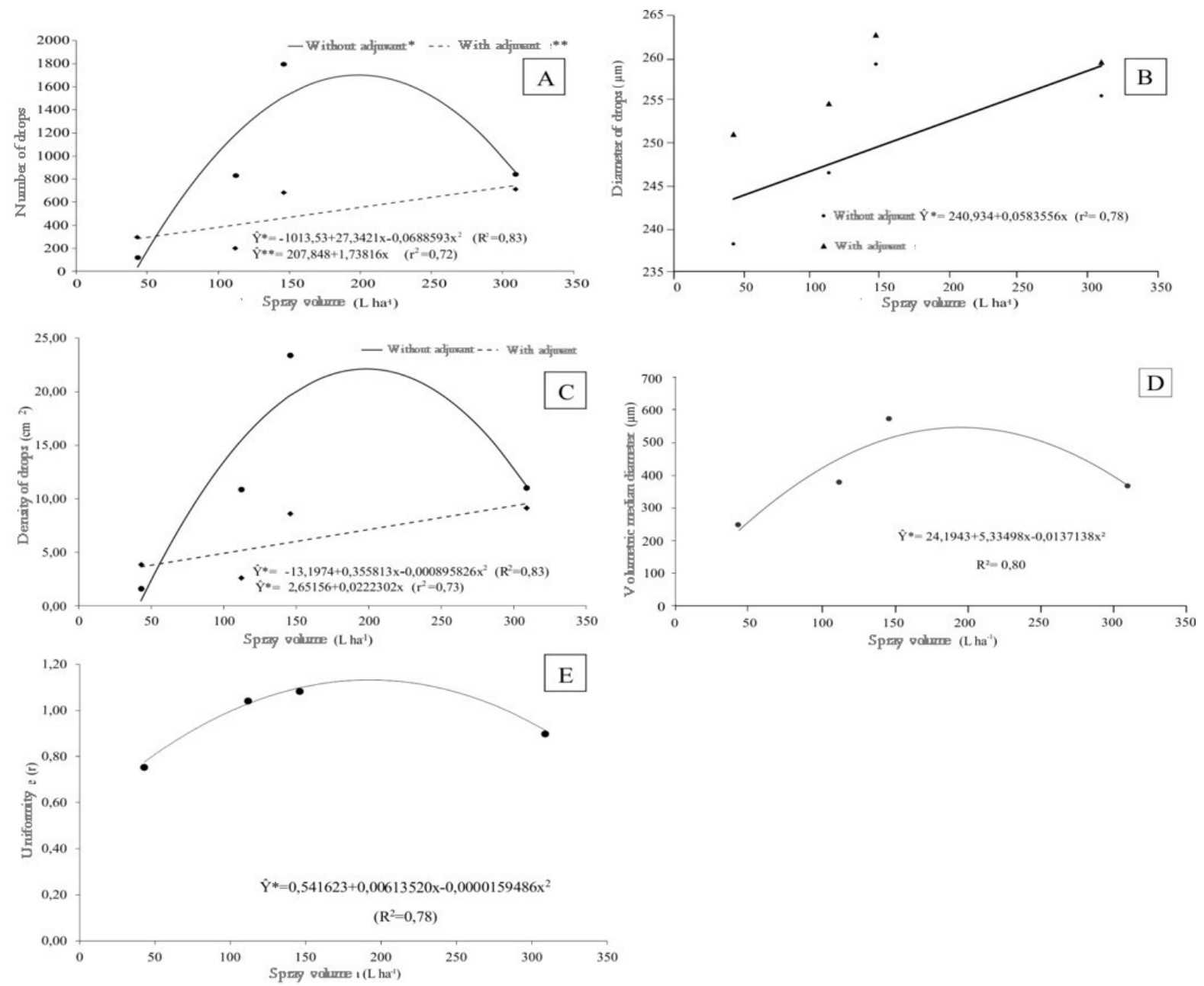

* Significant at 5\% probability, by the regression analysis of variance.

FIGURE 1 - Estimate of number (A), volumetric mean diameter (B), density (C), uniformity coefficient (D) and mean diameter (E) of droplets on water-sensitive cards after spraying in a coffee plantation with Brilliant Blue tracer, with and without the addition of adjuvant, as a function of spray volume. São Desidério, BA, 2016.

Without the addition of adjuvant to the spray, there was an increase in the number of drops up to the volume of $198.54 \mathrm{~L} \mathrm{ha}^{-1}$, reaching a maximum average number of 1,700 drops per water-sensitive card, an increase of $1406 \%$ in relation to the lowest volume. From this volume $\left(198.54 \mathrm{~L}^{\mathrm{a}}\right.$ $\left.{ }^{1}\right)$, there was a decrease in the number of drops collected in the cards until the highest volume studied (309 $\mathrm{L} \mathrm{ha}^{-1}$ ) (Figure 1A). With the addition of the adjuvant to the spray, the volume effect was linear and positive, that is, the number of drops increases as a function of volume increase (Figure 1A). At the lowest spray volume (43 $\left.\mathrm{L} \mathrm{ha}^{-1}\right)$, the mean number of drops was 295 , whereas at the highest volume studied ( $\left.309 \mathrm{~L} \mathrm{ha}^{-1}\right)$, the average number of drops was 711, that is, an increase of
$241 \%$ with the addition of adjuvant to the spray. In the absence of the adjuvant, the droplet diameter increased with increasing spray volume (Figure 1B). At the lowest spray volume (43 $\left.\mathrm{L} \mathrm{ha}^{-1}\right)$, the diameter was $238 \mu \mathrm{m}$, while the largest diameter $(259 \mu \mathrm{m})$ was reached at the volume $146 \mathrm{~L} \mathrm{ha}^{-1}$, that is, an increase of $8.8 \%$. When the adjuvant was added to the spray, although it had a significant effect, no significant model was found to explain the behavior of drop diameter in spray added with adjuvant. At the lowest spray volume $(43 \mathrm{~L}$ $\left.\mathrm{ha}^{-1}\right)$, the diameter was $251 \mu \mathrm{m}$, while the largest diameter $(262 \mu \mathrm{m})$ was also obtained at $146 \mathrm{~L} \mathrm{ha}^{-1}$. The results of diameter indicated the formation of medium drops, considering that very small drops have a difficult reading by the software, 
below 50 microns (HOFFMAN; HEWITT, 2005) or 80 microns (SALYANI; FOX, 1994). Another characteristic that may have affected this result is the fact that the analyzed target is artificial it does not have the same morpho-anatomical properties of the natural targets that are mostly crop leaves (NASCIMENTO et al., 2013).

A behavior similar to the number of drops occurred with density, due to the close correlation between such variables. There was a quadratic effect of the volume for the treatments without adjuvant, increasing the density up to the volume of $198.07 \mathrm{~L} \mathrm{ha}^{-1}$, reaching a maximum value of 22.13 (drops $\mathrm{cm}^{-2}$ ), an increase of $1418 \%$ in relation to the lowest volume, decreasing from there to the maximum volume studied $\left(309 \mathrm{~L} \mathrm{ha}^{-}\right.$ $\left.{ }^{1}\right)$. With the addition of the adjuvant, the effect was linearly positive, indicating that density increases as a function of the increase in application volume (Figure 1C).

When analyzing the interaction of the factors, there were significant differences in the number of drops only at the intermediate volumes, $112 \mathrm{~L} \mathrm{ha}^{-1}$ and $146 \mathrm{~L} \mathrm{ha}^{-1}$, with higher values in the treatments without adjuvant (Table 1). Thus, as expected as a function of the results for number of drops, higher densities were also obtained at the intermediary volumes, $112 \mathrm{~L} \mathrm{ha}^{-1}$ and $146 \mathrm{~L} \mathrm{ha}^{-1}$, with significantly higher densities in the treatments without adjuvant for the same volumes (Table 1). However, the density values obtained in this study can be considered low if the recommendations for application of insecticides are taken into account. For these pesticides, Matthews (1992) recommends drops with a diameter of 50 to 200 $\mu \mathrm{m}$, resulting in a density around 50 to 70 drops $\mathrm{cm}^{-2}$. Other recommendations regarding drop density for insecticides are found in the literature, such as bands from 20 to 30 or 40 to 60 drops $\mathrm{cm}^{-2}$ (SANTOS, 2010). A reduction in the surface tension for the Aureo adjuvant has already been verified (MADUREIRA et al., 2015). However, it should be considered that the fact that the adjuvant is a methylated soybean oil ester (MSO) can increase drop size. Water-sensitive cards were placed on the adaxial surface of the leaves in the upper third of the plants and, in this location, the leaf insertion in the branches, depending on the variety, is $45^{\circ}$, which may have contributed to the selection of drops in a narrow band of size variation. Still, it is appropriate to mention that the water-sensitive card is a surface that hardly exhibits drops smaller than $50 \mu \mathrm{m}$, the sampling surface may have become selective.
However, the adjuvant factor did not interfere with the volumetric mean diameter (VMD) of the drop spectrum. Differences in VMD were only verified in relation to spray volumes. A quadratic effect of the volumes in VMD was observed, with increases up to the maximum point of the curve (volume of 194.51 $\mathrm{L} \mathrm{ha}^{-1}$ ), reaching $543.05 \mu \mathrm{m}$, decreasing from that volume (Figure 1D). The volume of $43 \mathrm{~L}$ $\mathrm{ha}^{-1}$ allowed the formation of medium droplets, while the volumes of $112 \mathrm{~L} \mathrm{ha}^{-1}$ and $309 \mathrm{~L} \mathrm{ha}^{-1}$ resulted in thick drops and, at the volume $146 \mathrm{~L}$ $\mathrm{ha}^{-1}$, very thick droplets were generated, according to the classification of the British Crop Protection Council - BCPC (SOUZA; PALLADINI, 2007) (Table 2). Although the manufacturers of the tips used in this study classify them as producers of very fine drops and with a high risk of drift, the results indicated the formation of medium, thick and very thick drops, presenting low risk of drift and runoff. Several authors report that, in general, VMD values below $250 \mu \mathrm{m}$ indicate potential risk of drift, which is mainly due to drops smaller than $100 \mu \mathrm{m}$ and below $50 \mu \mathrm{m}$, frequently evaporate before reaching the target. In contrast, VMD values greater than $500 \mu \mathrm{m}$ suggest runoff problems, which commonly occur with droplets larger than $800 \mu \mathrm{m}$ (CUNHA et al., 2003). Rodrigues et al. (2012) verified that the variables drop density and VMD influence the mortality of leaf miner when the insecticide is cartap hydrochloride. The model defined by the authors made it possible to infer that, for an estimated mortality of $90 \%$ of the pest, it would be necessary to use density of 170 drops $\mathrm{cm}^{-2}$ with VMD of $200 \mu \mathrm{m}$. The data obtained in this study on drop density do not approach the model defined by Rodrigues et al. (2012), in which the volume of $43 \mathrm{~L} \mathrm{ha}^{-1}$ yielded VMD (247.06 $\mu \mathrm{m})$ closer to the said model $(200 \mu \mathrm{m})$. One of the hypotheses to explain the low droplet density and high VMD value, which resulted in thick and very thick drops, may be related to temperature and relative humidity conditions at the time of application, especially regarding the low relative humidity of the air, which varied from 42 to $58 \%$, below ideal values ( 70 to $90 \%$ ) and minimum and $60 \%$ recommended (VARGAS; GLEBER, 2005).

Significant differences in uniformity were observed only in relation to spray volumes, with quadratic effect of the volumes, and increasing values up to $192.34 \mathrm{~L} \mathrm{ha}^{-1}$, at which point the estimated uniformity reached $1.13(\mathrm{r})$. 
TABLE 1 - Number and density of drops in water-sensitive cards after spraying in a coffee plantation with Brilliant Blue tracer, with and without the addition of adjuvant, as a function of spray volume. São Desidério, BA, 2016.

\begin{tabular}{ccccccc}
\hline \multirow{2}{*}{$\begin{array}{c}\text { Spray volume } \\
\left(\mathrm{L} \mathrm{ha}^{-1}\right)\end{array}$} & $\begin{array}{c}\text { Without } \\
\text { adjuvant }\end{array}$ & With adjuvant & Mean & \multicolumn{3}{c}{ Density of drops $\left(\right.$ drops $\left.\mathrm{cm}^{-2}\right)$} \\
\cline { 2 - 7 } 43 & $120.93 \mathrm{~A}$ & $295.60 \mathrm{~A}$ & 208.27 & $1.57 \mathrm{~A}$ & $3.83 \mathrm{~A}$ & 2.70 \\
112 & $832.93 \mathrm{~A}$ & $201.20 \mathrm{~B}$ & 517.07 & $10.83 \mathrm{~A}$ & $2.60 \mathrm{~B}$ & 6.71 \\
146 & $1795.67 \mathrm{~A}$ & $683.70 \mathrm{~B}$ & 1239.68 & $23.37 \mathrm{~A}$ & $8.60 \mathrm{~B}$ & 15.98 \\
309 & $841.37 \mathrm{~A}$ & $711.17 \mathrm{~A}$ & 776.27 & $10.97 \mathrm{~A}$ & $9.13 \mathrm{~A}$ & 10.05 \\
\hline $\mathrm{CV}(\%)$ & 35.64 & & 35.06 & \\
\hline
\end{tabular}

*Means followed by the same letter in the row do not differ by the Tukey test at $5 \%$ significance.

TABLE 2 - Volumetric mean diameter (VMD) of water-sensitive cards after spraying in a coffee plantation with Brilliant Blue tracer, as a function of spray volume. São Desidério, BA, 2016

\begin{tabular}{|c|c|c|c|}
\hline \multirow{2}{*}{$\begin{array}{l}\text { Spray volume } \\
\left(\mathrm{L} \mathrm{ha}^{-1}\right)\end{array}$} & \multirow[t]{2}{*}{$\operatorname{VMD}(\mu \mathrm{m})$} & \multicolumn{2}{|c|}{ Drop classification } \\
\hline & & BCPC Standard* & Manufacturer \\
\hline 43 & $247.06 \mathrm{~b}$ & Medium & Very fine \\
\hline 112 & $378.45 \mathrm{ab}$ & Thick & Very fine \\
\hline 146 & $573.18 \mathrm{a}$ & Very thick & Very fine \\
\hline 309 & $365.50 \mathrm{ab}$ & Thick & Very fine \\
\hline CV (\%) & 44.93 & & \\
\hline
\end{tabular}

*British Crop Protection Council

All treatments presented homogeneous behavior, since they present a coefficient below the threshold of 1.4 (Figure 1E). According to Matuo (1990), uniformity values with coefficients above 1.4 characterize heterogeneous sprays. The dispersion coefficient (r), expressed by drop uniformity, was significantly higher when spraying was performed without the addition of the adjuvan although, under the condition of addition of the adjuvant, the spray was also considered homogeneous (below 1.4) (Table 3).

As for the quantitative aspect of spraying, a significant effect of spray volume on the Brilliant Blue tracer deposit was observed, with no effect of the adjuvant and the interaction between the factors. The regression analysis indicated a positive linear effect of nozzle volume on the deposit, that is, the deposit increases as a function of the volume increase, ranging from 0.03 (43 L $\mathrm{ha}^{-1}$ ) to $0.16 \mu \mathrm{L} \mathrm{cm}^{-2}$ (309 $\mathrm{L} \mathrm{ha}^{-1}$ ) (Figure 2). These results were expected, since the spraying of larger spray volumes frequently results in larger deposits, as already verified in coffee (RODRIGUES et al., 2010; FERREIRA et al., 2013). In coffee fruits, Miranda et al. (2012) also obtained significantly higher deposits at volumes of 300 and $600 \mathrm{~L} \mathrm{ha}^{-1}$, compared to $150 \mathrm{~L} \mathrm{ha}^{-1}$.

In the study of the efficiency of cartap hydrochloride in the control of leaf miner, there was a significant effect of the volume factor of the syringe on the infestation of leaf miner at 15 and 30 days after application (DAA). The adjuvant factor and the interaction between the volume and adjuvant factors did not show any significant interaction during all evaluation periods. It was also observed that there was an effect of the interaction of the factors volume and adjuvant in relation to the control on the infestation by leaf miner at 15 and 30 DAA.

In the previous analysis of leaf miner infestation, there was homogeneity in pest population, not occurring significant differences between the plots of the experimental area, with infestations varying from $10.42 \%$ to $16.67 \%$ (Table 4). At the beginning, it can be considered that this level of infestation is low since, according to Souza and Reis (2000), for hot regions, the level of $20 \%$ of infestation must be used as the control level. 
TABLE 3 - Uniformity of spraying on water-sensitive cards in coffee leaves, as a function of the addition or not of adjuvant. São Desidério, BA, 2016.

\begin{tabular}{ccc}
\hline Characteristic & Without adjuvante & With adjuvante \\
\hline Diameter & $249.835 \mathrm{~B}$ & $256.897 \mathrm{~A}$ \\
Uniformity $(\mathrm{r})$ & $1.084 \mathrm{~A}$ & $0.802 \mathrm{~B}$ \\
\hline
\end{tabular}

*Means followed by the same letter in the row do not differ by the Tukey test at $5 \%$ significance.

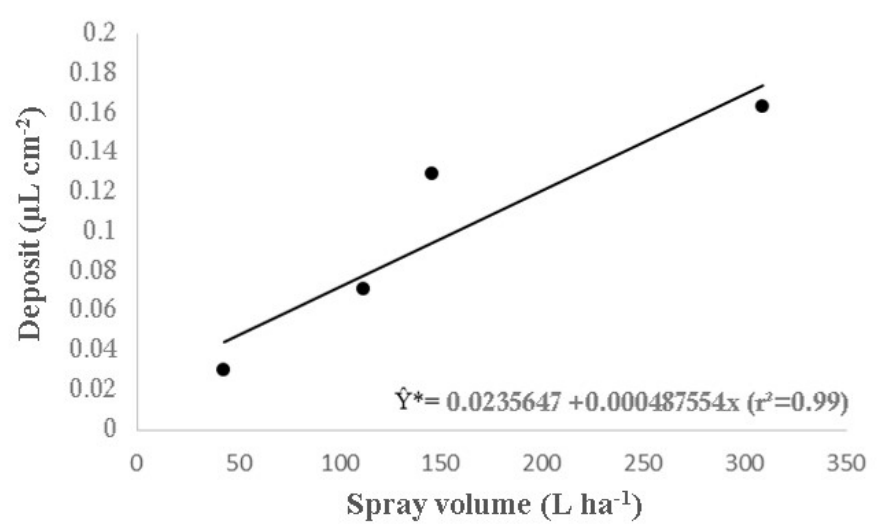

FIGURE 2 - Estimate of deposit of the Brilliant Blue tracer in coffee leaves, as a function of the applied spray volume. São Desidério, BA, 2016

However, in practice, in the West region of Bahia, technicians and coffee growers adopt chemical control when infestations are around $5 \%$, since the region meets optimal conditions for the development of the pest, resulting in shorter cycle and greater number of generations per year. At 15 DAA, treatments at $43 \mathrm{~L} \mathrm{ha}^{-1}$ and 146 $\mathrm{L} \mathrm{ha}^{-1}$ with and without adjuvant and $112 \mathrm{~L} \mathrm{ha}^{-1}$ without adjuvant differed from the control, with significantly lower infestations. However, only treatments $43 \mathrm{~L} \mathrm{ha}^{-1}$ (without and with adjuvant) and $146 \mathrm{~L} \mathrm{ha}^{-1}$ (with adjuvant) resulted in efficiencies above $80 \%$, specifically $82.63 \%, 93.06 \%$ and $93.69 \%$, respectively (Table 4). An insecticide is considered efficient when it reaches, at least, $80 \%$ efficiency in the control of a pest (MORAIS et al., 2016). At 30 DAA, only the $309 \mathrm{~L} \mathrm{ha}^{-1}$ treatment with the addition of adjuvant behaved similarly to the control, while the others resulted in significantly lower infestations. However, in none of the treatments, efficiency was observed above $80 \%$; only the $43 \mathrm{~L} \mathrm{ha}^{-1}$ treatment without adjuvant allowed a close value, $71.43 \%$. In the last evaluation (45 DAA), all treatments matched the control, reaching levels above the pest control level for that region (20\%) (Table 4). The obtained results partially agree with those presented by Benvenga et al. (2011). These authors verified a significant reduction in leaf miner infestation using the same insecticide without adjuvant at the dose of $0.7 \mathrm{~kg} \mathrm{pc}^{-1}$ and with $370 \mathrm{~L} \mathrm{ha}^{-1}$ up to 70 days after application. Rodrigues et al. (2012) obtained in their study, high efficiency (93\%) after 72 hours of having sprayed with Cartap PS 500 in the Minas Gerais state.

At the end of the experiment it was observed that the pest was reestablished, probably due to the climatic and management conditions that favor the rapid cycle of the pest, around 20 days, and also the migration of the pest from neighboring properties. Another aspect to be considered is the short residual power of the product. Tomizawa and Endo (1972) found that the fraction with biological activity of cartap hydrochloride in rice leaves reached a maximum concentration on the seventh day after application, declining rapidly until the 15 th day, with the remaining of a small amount of the active fraction up to 30 days. It is possible that the degradation behavior of the product in coffee is similar, which would explain the levels of infestation of leaf miner observed after the application of this insecticide. It is also important to consider that irrigation may have contributed to the reduction in the insecticide action by washing the product deposits. 
TABLE 4 - Previous Leucoptera coffeella infestation (INF) in coffee and at 15, 30 and 45 days after application (DAA) of the insecticide cartap hydrochloride and Agronomic Efficiency (AE) of the insecticide, as a function of different spray volumes, with or without adjuvant. São Desidério, BA, 2016.

\begin{tabular}{|c|c|c|c|c|c|c|c|}
\hline \multirow{3}{*}{$\begin{array}{c}\text { Treatment } \\
\text { Volume }\left(\mathrm{L} \mathrm{ha}^{-1}\right)\end{array}$} & \multicolumn{7}{|c|}{ Samplings } \\
\hline & \multirow{2}{*}{$\begin{array}{c}\text { Previous } \\
\text { INF } \\
(\%)\end{array}$} & \multicolumn{2}{|c|}{$15 \mathrm{DAA}$} & \multicolumn{2}{|c|}{$30 \mathrm{DAA}$} & \multicolumn{2}{|c|}{$45 \mathrm{DAA}$} \\
\hline & & $\begin{array}{l}\text { INF } \\
(\%)\end{array}$ & $\begin{array}{l}\mathrm{AE}^{3} \\
(\%)\end{array}$ & $\begin{array}{l}\text { INF } \\
(\%)\end{array}$ & $\begin{array}{l}\mathrm{AE} \\
(\%)\end{array}$ & $\begin{array}{l}\text { INF } \\
(\%)\end{array}$ & $\begin{array}{l}\mathrm{AE} \\
(\%)\end{array}$ \\
\hline 43 without $^{1}$ & $12.50 \mathrm{a}^{*}$ & $1.74 \mathrm{~b}^{* *}(3.12)$ & 82.63 & $6.25 \mathrm{~b}$ & 71.43 & $23.96 \mathrm{a}$ & 17.09 \\
\hline 43 with $^{2}$ & $10.42 \mathrm{a}$ & $1.11 \mathrm{~b}(1.04)$ & 93.06 & $13.54 \mathrm{~b}$ & 25.74 & $23.96 \mathrm{a}$ & 0.54 \\
\hline 112 without & $12.50 \mathrm{a}$ & $2.55 \mathrm{~b}(6.25)$ & 60.21 & $15.62 \mathrm{~b}$ & 28.59 & $34.37 \mathrm{a}$ & -18.93 \\
\hline 112 with & $10.42 \mathrm{a}$ & $3.04 \mathrm{a}(9.37)$ & 37.44 & $14.58 \mathrm{~b}$ & 20.04 & $23.95 \mathrm{a}$ & 0.58 \\
\hline 146 without & $11.46 \mathrm{a}$ & $2.78 \mathrm{~b}(7.29)$ & 55.74 & $12.50 \mathrm{~b}$ & 37.67 & $20.83 \mathrm{a}$ & 21.38 \\
\hline 146 with & $11.46 \mathrm{a}$ & $1.11 \mathrm{~b}(1.04)$ & 93.69 & $10.42 \mathrm{~b}$ & 48.04 & $33.33 \mathrm{a}$ & -25.80 \\
\hline 309 without & $11.46 \mathrm{a}$ & 3.04 a (9.37) & 43.11 & $12.50 \mathrm{~b}$ & 37.67 & $28.12 \mathrm{a}$ & -6.13 \\
\hline 309 with & $12.50 \mathrm{a}$ & $3.30 \mathrm{a}(11.46)$ & 36.21 & $22.92 \mathrm{a}$ & -4.79 & $47.91 \mathrm{a}$ & -65.78 \\
\hline Control & $16.67 \mathrm{a}$ & $4.90 \mathrm{a}(23.96)$ & - & $29.17 \mathrm{a}$ & - & $38.54 \mathrm{a}$ & - \\
\hline DMS & 7.50 & 2.04 & & 11.09 & & 23.23 & \\
\hline CV (\%) & 25.71 & 32.44 & & 30.24 & & 31.68 & \\
\hline
\end{tabular}

${ }^{1}$ Without adjuvant; ${ }^{2}$ With adjuvant; ${ }^{3}$ Agronomic Efficiency (Henderson; Tilton, 1955); *Means followed by the same lowercase letter in the column do not differ by the Dunnett test at $5 \%$ significance; ${ }^{* *}$ Statistical analysis carried out on data processed in $\sqrt{ }(x+0.5)$; Untransformed means in parentheses.

In this study, the highest volume $\left(309 \mathrm{~L} \mathrm{ha}^{-1}\right)$ with and without the addition of the adjuvant proved to be inefficient for the control of leaf miner in all evaluation period. At this volume, rates of infestation reduction ranged from $65.78 \%$ to $43.11 \%$ (Table 4). Efficiency results from the treatment at the lowest volume $\left(43 \mathrm{~L} \mathrm{ha}^{-1}\right)$ were not expected, as most of the qualitative aspects of spraying and deposition indicated better spray quality at intermediate volumes (112 and $146 \mathrm{~L} \mathrm{ha}^{-}$ ${ }^{1}$ ). Another aspect to be observed is that the addition of the adjuvant to the spray, while allowing a significant reduction in spray quality, appears to have contributed to improving the effectiveness of the product in certain treatments. According to Cunha and Peres (2010), the adjuvants alter the physicochemical characteristics of the spray, such as viscosity and surface tension, improve drop spread, adhesion, as well as increase the absorption of the active ingredient, among other benefits. Mineral or vegetable oils are additives that act by dissolving the fats components of the cuticle and cell membranes.

In this study, it can be hypothesized that the Aureo adjuvant has potentiated the translaminar effect of the insecticide, contributing to the achievement of higher efficiency rates at volumes whose qualitative aspects did not show up to the desirable standards, such as the volume $43 \mathrm{~L} \mathrm{ha}^{-1}$. According to Araújo and Raetano (2011), the lack of knowledge of the interaction between adjuvants and active ingredients, which can have several implications, can be observed. In this study, the interaction seems to have been positive regarding the control of leaf miner, deserving to be better studied.

Regarding the impact of spraying on the natural parasitism of leaf miner, it was observed that the rates of parasitism were very low, varying from 0 to $3.8 \%$ in the previous evaluation and from 0 to $11.2 \%$ after spraying. Rates of parasitism reduction $(\mathrm{PR})$ varied between the volumes and dates of evaluation. At 15 DAA, the volumes $146 \mathrm{~L} \mathrm{ha}^{-1}$ and $309 \mathrm{~L} \mathrm{ha}^{-1}$ without the addition of adjuvant made possible to classify the insecticide as toxic and moderately toxic, respectively, and the other treatments were considered innocuous. At 30 DAA, the behavior of cartap hydrochloride was similar, with treatments $112 \mathrm{~L} \mathrm{ha}^{-1}$ and 309 $\mathrm{L} \mathrm{ha}^{-1}$ without adjuvant classified as toxic and volume $112 \mathrm{~L} \mathrm{ha}^{-1}$ with adjuvant as moderately toxic. At $45 \mathrm{DAA}$, only $43 \mathrm{~L} \mathrm{ha}^{-1}$ treatment without adjuvant became moderately toxic while, at $112 \mathrm{~L}$ $\mathrm{ha}^{-1}$, it remained as toxic (Table 5). 
TABLE 5- Parasitism Index (PI \%) and respective Parasitism Reduction (PR \%) as a function of evaluation periods, before (previous) and at 15, 30 and 45 days after application of insecticides - DAA. São Desidério, BA, 2016.

\begin{tabular}{cccccccc}
\hline Treatments & \multicolumn{7}{c}{ Parasitism Index (\%) and Parasitism Reduction (\%) } \\
\hline $\begin{array}{c}\text { Volume } \\
\left(\mathrm{L} \mathrm{ha}^{-1}\right)\end{array}$ & $\begin{array}{c}\text { PI } \\
\text { Previous } \\
(\%)\end{array}$ & $\begin{array}{c}\text { PI } \\
15 \text { DAA } \\
(\%)\end{array}$ & $\begin{array}{c}\text { PR }^{3} \\
(\%)\end{array}$ & $\begin{array}{c}\text { PI DAA } \\
(\%)\end{array}$ & $\begin{array}{c}\text { PR } \\
(\%)\end{array}$ & $\begin{array}{c}\text { PI } \\
45 \text { DAA } \\
(\%)\end{array}$ & $\begin{array}{c}\text { PR } \\
(\%)\end{array}$ \\
\hline 43 without $^{1}$ & 0.0 & 3.2 & $15.79 \mathrm{~N}^{4}$ & 5.6 & $-47.37 \mathrm{~N}$ & 1.5 & $60.53 \mathrm{M}$ \\
43 with $^{2}$ & 0.0 & 3.2 & $15.79 \mathrm{~N}$ & 4.3 & $-13.16 \mathrm{~N}$ & 3.2 & $15.79 \mathrm{~N}$ \\
112 without & 2.9 & 5.1 & $-34.21 \mathrm{~N}$ & 0.0 & $100.00 \mathrm{~T}$ & 0.0 & $100.00 \mathrm{~T}$ \\
112 with & 0.0 & 4.2 & $-10.53 \mathrm{~N}$ & 1.4 & $63.16 \mathrm{M}$ & 3.7 & $2.63 \mathrm{~N}$ \\
146 without & 2.2 & 0.0 & $100.00 \mathrm{~T}$ & 1.9 & $50.00 \mathrm{~N}$ & 11.2 & $-194.74 \mathrm{~N}$ \\
146 with & 2.3 & 4.2 & $-10.53 \mathrm{~N}$ & 2.9 & $23.68 \mathrm{~N}$ & 4.8 & $-26.36 \mathrm{~N}$ \\
309 without & 0.0 & 1.4 & $63.16 \mathrm{M}$ & 0.0 & $100.00 \mathrm{~T}$ & 6.0 & $-57.89 \mathrm{~N}$ \\
309 with & 2.2 & 2.9 & $23.68 \mathrm{~N}$ & 3.2 & $15.79 \mathrm{~N}$ & 5.0 & $-31.58 \mathrm{~N}$ \\
Control & 3.8 & 0.9 & - & 0.0 & - & 1.9 & - \\
\hline
\end{tabular}

${ }^{1}$ Without adjuvant, ${ }^{2}$ With ajuvant

${ }^{3}$ Parasitism Reduction determined by Abbott's formula (1925)

${ }^{4}$ Selectivity classification according to Boller et al. (2005), where: N: innocuous or slightly toxic; M: moderately toxic; T: toxic

Most of the studies available in the literature on the selectivity of insecticides to the natural enemies of the coffee tree, approach the selectivity in favor of predators, such as the predatory wasps of leaf miner (GUSMÃO et al., 2000; FRAGOSO et al., 2001), chrysopides (VILELA et al., 2010) and lady bug (ROCHA et al., 2010; 2011). In other cultures, studies have shown that cartap may reduce parasitism (PASINI et al., 2017) and affect the sex ratio (CARVALHO et al., 2003) of Trichogramma pretiosum Riley in tomato.

In general, the results indicate that it is possible to reduce by more than $50 \%$ the spray volume normally used by coffee growers (400 to $500 \mathrm{~L} \mathrm{ha}^{-1}$ ) for the control leaf miner, maintaining the effectiveness of the insecticide cartap hydrochloride and low impact on natural parasitism, especially when associated with the adjuvant to the soybean oil methyl ester-based adjuvant.

\section{CONCLUSIONS}

The qualitative-quantitative aspects of the sprays are affected by the applied spray volume, by the adjuvant and by the interaction of the factors. The intermediate volumes yielded better spraying quality without the presence of the adjuvant, with higher number and density of drops.
The spraying volume affected the deposit of the Brilliant Blue tracer in a linear and positive form.

The effectiveness of the insecticide cartape hydrochloride was prolonged longer with the lowest application volume and with adjuvant.

The impact of the insecticide cartape hydrochloride on parasitism varied as a function of the spray volume applied and time after application.

\section{ACKNOWLEDGEMENT}

The authors thank Agrícola Marçal and Fundação Bahia for their support in the execution of the works.

\section{REFERENCES}

ABBOTT, W. S. A method of computing the effectiveness of an inseticide. Journal of Economic Entomology, Lanham, v. 18, n. 1, p. 265-267, 1925.

ALVES, G. S.; CUNHA J. P. A. R.; PALLADINI, L. A. Seleção de traçadores para estudos de eficiência das aplicações de produtos fitossanitários. Planta Daninha, Viçosa, v. 32, n. 4, p. 861-870, 2014. 
ARAÚJO, D.; RAETANO, C. G. Adjuvantes de produtos fitossanitários. In: ANTUNIASSI, U. R.; BOLLER, W. Tecnologia de Aplicação para Culturas Anuais. Passo Fundo: Aldeia Norte, Botucatu, Fepap, p. 27-50, 2011.

BENVENGA, S. R. et al. Atabron 50 EC (clorfluazuron) no manejo do bicho-mineiro, Leucoptera coffeella, e influência sobre inimigos naturais no cafeeiro. In: CONGRESSO BRASILEIRO DE PESQUISA CAFEEIRA, 2011, Poços de Caldas. Anais...Poços de Caldas: MAPA - Fundação Procafé, Nov. 2011, p. 255-37.

BOLLER, E.F. et al. Working document on selectivity of pesticides. International Organization for Biological and Integrated Control of Noxious Animals and Plants. Available on: <http://www. iobc.ch/2005/ Working\%Document\%20Pesticides Explanations.pdf>. Accessed: Apr 6, 2017.

CARVALHO, G. A.; PARRA, J. R. P.; BAPTISTA, G. C. Bioatividade de produtos fitossanitários utilizados na cultura do tomateiro (Lycopersicon esculentum Mill.) a Trichogramma pretiosum Riley, 1879 (Hymenoptera: Trichogrammatidae) nas gerações F1 e F2. Ciência e Agrotecnologia, Lavras, v. 27, n. 2, p. 261-270, Mar/ Apr. 2003.

CASTELlANI, M. A.; MELO, T. L.; MENEZES, M. A. P. Desafios para o Manejo do Bicho-mineiro. Aiba Rural, Barreiras, n. 5, ano II, p. 40-41, 2016.

CASTILHOS, R. V. et al. Selectivity of insecticides used in peach farming to larvae of Chrysoperla externa (Neuroptera: Chrysopidae) in semi-field conditions. Revista Caatinga, Mossoró, v. 30, n.1, p.109-115, Jan/ Mar. 2017.

CHAIM, A. Tecnologia de aplicação de agrotóxicos: fatores que afetam a eficiência e o impacto ambiental. In: SILVA, C. M. M. S.; FAY, E. F. (Ed.). Agrotóxicos e ambiente. Jaguariúna: Embrapa Meio Ambiente, p. 289-317, 2012.

CONAB - Companhia Nacional de Abastecimento. Acompanhamento da Safra Brasileira Café Safra 2016, segunda estimativa maio/2016/. Companhia Nacional de Abastecimento. Brasília: Conab, v. 3, n. 4, Dez. 2016, 82 p.

CUNHA, J. P. A. R. da et al. Avaliação de estratégias para redução da deriva de agrotóxicos em pulverizações hidráulicas. Planta Daninha, Viçosa, v. 21, n. 2, p. 325-332, 2003.
CUNHA, J. P. A. R. da; PERES, T. C. M. Influência de pontas de pulverização e adjuvante no controle químico da ferrugem asiática da soja. Acta Scientiarum Agronomy, Maringá, v. 32, n. 4, p. 597-602, 2010.

DECARO JUNIOR, S. T. et al. Reducing spray volume for the control of Leucoptera coffeella (Lepidoptera: Lyonetiidae) in coffee plants. Coffee Science, Lavras, v. 10, n. 4, p. 491 - 498, Oct/Dez. 2015.

FERREIRA, M. da C. et al. Qualidade da aplicação de inseticida em amendoim (Arachis hypogaea L.), com e sem adjuvantes na calda, sob chuva simulada. Bioscience Journal, Uberlândia, v. 29, Sup. 1, p. 14311440, Nov. 2013.

FRAGOSO, D. B. et al. Selectivity of insecticides to predatory wasps of Leucoptera coffeella (Guer.Menev.) (Lepidoptera: Lyonetiidae). Neotropical Entomology, Londrina, v. 30, n. 1, p. 139-143. 2001.

GITIRANA NETO, J. et al. Deposição de calda promovida por pulverizadores empregados na cafeicultura de montanha. Coffee Science, Lavras, v. 11, n. 2, p. 267-275, Apr/June. 2016.

GUSMÃO, M. R. et al. Seletividade fisiológica de inseticidas a Vespidae e predadores do bicho-mineirodo-cafeeiro. Pesquisa Agropecuária Brasileira, Brasília, v. 35, n. 4, p. 681-686, Apr. 2000.

HENDERSON, C.F.; TILTON, E.W. Tests with acaricides against the brown wheat mite. Journal of Economic Entomology, Lanham v. 48, n. 2, p.157161, Apr. 1955.

HOFFMAN, W. C.; HEWITT, A. J. Comparison of three imaging systems for water sensitive papers. Applied Engineering in Agriculture, St. Joseph, v. 21, n. 6, p. 961-964, 2005.

MADUREIRA, R. P.; RAETANO, C. G; CAVALIERI, J.D. Interação pontas-adjuvantes na estimativa do risco potencial de deriva de pulverizações. Revista Brasileira de Engenharia Agrícola e Ambiental, Campina Grande, v. 19, n. 2, p.180-185, 2015.

MATTHEWS, G.A. Pestecide application methods. 2th ed. New York: Longman, 450p. 1992.

MATUO, T. Técnicas de aplicação de defensivos agrícolas de defensivos agrícolas. Jaboticabal: FUNEP, p. 03-86, 1990. 
MELO, T. L. et al. Comunidades de Parasitóides de Leucoptera coffeella (Guérin-Meneville \& Perrotet, 1842) (Lepidoptera: Lyonetiidae) em cafeeiros nas regiões Oeste e Sudoeste da Bahia. Ciência e Agrotecnologia, Lavras, v. 31, n. 4, p. 966-972, July/ Aug. 2007.

MIRANDA, G. R. B. et al. Avaliação dos depósitos da pulverização em frutod de cafeeiro utilizando dois equipamentos associados a diferentes volumes de calda. Revista Agroambiental, Pouso Alegre, v. 4, n. 1, p. 15-20, Apr. 2012.

MORAIS, J. L. C. et al. Lambda-cyhalothrin efficiency on fruit borer control and quali-quantitative spraying aspects in a pinecone crop. Ciência e Agrotecnologia, Lavras, v. 40, n. 3, p. 288-297, May/June. 2016.

NASCIMENTO, B. A. et al. Determinação do tamanho da amostra de papéis hidrossensíveis em experimentos ligados à tecnologia de aplicação. Semina: Ciências Agrárias, Londrina, v. 34, n. 6, p. 2687-2696, Nov/Dec. 2013.

OLIVEIRA, R. B. de et al. Potential of adjuvants to reduce drift in agricultural spraying. Engenharia Agrícola, Jaboticabal, v. 34, n.5, p. 986-992, Sept/Oct. 2013.

PASINI, R. A. et al. Ação residual de agrotóxicos pulverizados em plantas de milho sobre Trichogramma pretiosum. Revista Ceres, Viçosa, v. 64, n. 3, p. 242249, May/June. 2017.

REIS, P. R.; SOUZA, J. C. Insetos na folha. Cultivar. Pelotas, v. 4, n. 39, p. 30-33, 2002.

RIBEIRO JUNIOR, J. I. Análises Estatísticas no SAEG. Viçosa, Universidade Federal de Viçosa, 2001, 250 p.

ROCHA, L. C. D. et al. Seletividade fisiológica de inseticidas utilizados em cultura cafeeira sobre ovos e adultos de Cryptolamus montrouzieri Mulsant. Arquivos do Instituto Biológico, São Paulo, v. 77, n. 1, p. 119-127, Jan/Mar. 2010.

ROCHA, L. C. D. et al. Seletividade fisiológica de inseticidas utilizados em cultura cafeeira para larvas de Cryptolamus montrouzieri Mulsant. Ciência Rural, Santa Maria, v. 41, n. 6, p. 939-946, Jun. 2011.

RODRIGUES, A. C. P. et al. Avaliação qualitativa e quantitativa na deposição de calda de pulverização em Commelina benghalensis. Planta Daninha, Viçosa, v. 28, n. 2, p. 421-428, 2010.

RODRIGUES, G. J. et al. Otimização da pulverização de inseticidas visando o controle do bicho-mineiro do cafeeiro. Revista Agrotecnologia, Anápolis, v. 3, n. 1, p. 70-80, 2012.
SALYANI, M.; FOX, R. D. Performance of image analysis for assesment of simulated spray droplet distribution. Transaction of ASAE, St. Joseph, v. 37, n. 4, p. 1083-1089, 1994.

SANTINATO, F. et al. Deposição da calda de pulverização em diferentes volumes vegetativos de Coffea arabica L. Coffee Science, Lavras, v. 12, n. 1, p. 69-73, Jan/Mar. 2017.

SANTOS, J. M. F. Tecnologia de aplicação de defensivos agrícolas, 2010. Available on: <http:// www.biologico.sp.gov.br/rifib/IIIRifib/109-116.pdf>, Accessed Feb 15, 2017.

SILVA, J. E. R.; CUNHA, J. P. A. R. da; NOMELINI, Q. S. S. Deposição de calda em folhas de cafeeiro e perdas para o solo com diferentes taxas de aplicação e pontas de pulverização. Revista Brasileira de Engenharia Agrícola e Ambiental, Campina Grande, v. 18, n. 12, p. 1302-1306, 2014.

SOUZA, R. T. de; PALLADINI, L. A. Tecnologia para aplicação de produtos fitossanitários em videira. Circular Técnica 73, Embrapa: Bento Gonçalves, RS. 2007, 8p.

SOUZA, J. C.; REIS P. R. Pragas do cafeeiro reconhecimento e controle, Viçosa: CTP, 2000.154p.

SOUZA JÚNIOR, J. M. de et al. Determinação do índice de volume de pulverização para cultura do café. Coffee Science, Lavras, v. 12, n. 1, p. 82-90, Jan/ Mar. 2017.

TAVARES, R. M. et al. Tecnologia de Aplicação de inseticidas no controle de largarta-do-cartucho na cultura do milho. Revista de Milho e Sorgo, Sete Lagoas, v. 16, n. 1, p. 30-42, 2017.

TOMIZAWA, C.; ENDO, T. Movement of cartap hydrochloride in soil, paddy water and rice plant. Report from National Institute of Agricultural Sciences (Japan), submitted by Takeda Chemical Industries, Ltd. (Unpublished). 1972.

VARGAS, L.; GLEBER, L. Sistema de Produção de Ameixa Européia: Embrapa Uva e Vinho: Sistema de Produção 7. Dec. 2005. Available on: <https:// sistemasdeproducao.cnptia.embrapa.br/FontesHTML/ Ameixa/AmeixaEuropeia/index.htm $>$ Accessed Jan $15,2019$.

VILELA, M. et al. Seletividade de acaricidas utilizados em cafeeiro para larvas de crisopídeos. Revista Ceres, Viçosa, v. 57, n. 5, p. 621-628, Sept/Oct. 2010. 